University of Michigan Law School University of Michigan Law School Scholarship Repository

Articles

Faculty Scholarship

2009

\title{
Facts, Information, and the Newly Discovered Record in Pierson v. Post
}

James E. Krier

University of Michigan Law School, jkrier@umich.edu

Available at: https://repository.law.umich.edu/articles/238

Follow this and additional works at: https://repository.law.umich.edu/articles

Part of the Legal History Commons, and the Property Law and Real Estate Commons

\section{Recommended Citation}

Krier, James E. "Facts, Information, and the Newly Discovered Record in Pierson v. Post." Law \& Hist. Rev. 27, no. 1 (2009): 189-94.

This Article is brought to you for free and open access by the Faculty Scholarship at University of Michigan Law School Scholarship Repository. It has been accepted for inclusion in Articles by an authorized administrator of University of Michigan Law School Scholarship Repository. For more information, please contact mlaw.repository@umich.edu. 


\title{
Facts, Information, and the Newly Discovered Record in Pierson v. Post
}

\author{
JAMES E. KRIER
}

Unlike Professors Fernandez, Banner, and Donahue, I am not a legal historian; like them, however, I am much interested in the comings and goings of the famous old case about the fox. It figures significantly in my course on property and in my co-authored book on the subject. The background of the case is noted in the book and will be updated in the next edition to take account of Fernandez's discovery of the hitherto lost judgment roll in the case. ${ }^{1}$ Her find yields many facts, but, in my judgment, virtually no information. Facts are necessary to information, but not sufficient. A fact without purpose is useless; coupled with purpose, it becomes information. The information itself might be trivial, as it is in trivia games. Suppose you are playing a game, a trivia game, where stating the right fact wins you points. Suppose the name of William Blackstone's tailor was Jonas Maybird, and this is a fact you happen to know. Suppose you are asked, What was the name of William Blackstone's tailor? You answer correctly and win points. Outside the game, the name of Blackstone's tailor is just a fact; inside the game, it is information. Change the game to a scholarly one concerned with illuminating Blackstone's Commentaries on the Laws of England, and we are back to the name of Blackstone's tailor being just a worthless fact. For purposes of understanding Blackstone, I presume that

1. For my treatment of Pierson and related matters, see Jesse Dukeminier, James E. Krier, Gregory S. Alexander, and Michael H. Schill, Property, 6th ed. (New York: Aspen Publishers, 2006), 17-23, 28-35, 45-50. My update to take account of the record in the case will also note a few other articles discussing the background of Pierson that appeared too late to be included in the present edition, including two mentioned by Fernandez. See Andrea McDowell, "Legal Fictions in Pierson v. Post," Michigan Law Review 105 (2007): 735; Bethany Berger, "It's Not About the Fox: The Untold History of Pierson v. Post," Duke Law Journal 55 (2006): 1089.

James E. Krier is the Earl Warren DeLano Professor, University of Michigan Law School<jkrier@umich.edu>. 
to know the name of his tailor is to know a fact that carries no information; it has no purpose in the enterprise. Change the game again, to a study of famous tailors in eighteenth-century England, and then once again the Maybird-Blackstone connection is not just a fact, but a piece of information. So it all depends on the game.

As I said, my game is not legal history. In my game, the aim is to study, teach, and critique the law of property, the institution of property-its doctrines, its functions, its justifications. For these purposes, the Pierson record is unilluminating.

Why, then, will I update my book by noting the Fernandez account? Because, as she says, the case is a famous old chestnut; because, as Banner says, it has become "an icon of legal education," and studying it is "a rite of passage during the first year of law school." Students come across many such iconic cases as they travel along. Enterprising authors have built collections around the cases, accounts that supplement them with all sorts of background material. My colleague Brian Simpson, a legal historian, put together such a collection some dozen years ago (though he ignored Pierson). ${ }^{3}$ Since then, others have joined in. Foundation Press publishes a Law Stories Series designed, says its website, to "bring landmark cases to life." There are to date at least twenty little volumes in the series, ranging over a wide variety of subjects-not just the common law subjects like property (the volume on property also ignores Pierson), contracts, and torts, but also tax law, corporate law, civil procedure, labor law, antitrust, employment discrimination, evidence, environmental law, immigration law, and so on.

Simpson has suggested what I take to be the spirit behind all this industry, namely "that we can obtain greater enjoyment and instruction from the study of cases if we discover more about them than is provided by law reports." 4 I agree with that sentiment and hence refer to background material in any number of instances as I teach my property course; some of the material is the product of original research, but most is based on published work. I know from my own experience, and from reports by other teachers, that students enjoy this material - much of which, I should add, amounts to little more than what newspapers call human interest stories. Much of it would be trivia, had it not a pedagogical purpose. It lightens the students' days and, I like to think, also ends up enlightening their understanding, if not always directly, then at least indirectly by provoking closer attention to whatever case happens to be up for consideration.

Banner writes that "the important thing about Pierson v. Post is no longer the abstract legal principle for which it might or might not stand. The

2. Stuart Banner, "21st Century Fox," Law and History Review 27 (Spring 2009): 188.

3. See A. W. Brian Simpson, Leading Cases in the Common Law (Oxford: Clarendon Press, 1995).

4. Ibid., at vii. 
important thing is the story of the fox." I hope he doesn't mean what he seems to say. Filling out the story of the fox, at least as it has been done thus far, has the pedagogical virtues I mentioned above, but little more. Little if any of the supplemental material published to date touches upon the thematic and conceptual richness of Pierson that make it such a remarkable introduction to the study of property.

Such as what? Here are some examples, all of which I explore as I consider the case with my students.

(1) The case is about the great issue of first possession as the means of becoming an owner, a matter considered by such notables as Hobbes and Locke and Hume and Blackstone in the seventeenth and eighteenth centuries. ${ }^{6}$ Their treatments all began by supposing a state of nature populated by ungoverned humans, each of whom was free to take from the common stock of resources-flora, fauna, land, water. What was taken became the individual property of whomever first removed it from the commons. This, it is widely believed, describes the actual genesis of property among humans. So how better to start a course on property than with a case like Pierson?

(2) And this especially because the holding of the case continues to be of enormous importance for reasons unmentioned by Fernandez, Banner, and Donahue. The majority decided that a wild animal goes to the hunter who actually kills, mortally wounds, or catches it, as opposed to the hunter first in hot pursuit. Today we call this principle the rule of capture, which courts went on to extend beyond wild animals (animals ferae naturae) to other resources ferae naturae-such common-pool resources as groundwater, oil, and gas, all of which, just like foxes and other wild animals, roam about in their natural state. Judges reasoned that these too should be subject to the rule of capture. Is not oil under the ground just like a fox on the ground? Well, not exactly, but never mind. The analogy was drawn, with little thought about consequences. Thus began a body of law that promoted wasteful exploitation of many resources and continues to do so now (in the case, for example, of ocean fisheries). Pierson, in short, is sadly modern in its implications. It can be said without exaggeration to underlie (pun intended) the Persian Gulf War. ${ }^{7}$

5. Banner, "21st Century Fox," 188.

6. The works of Hobbes, Locke, and Hume appear in many editions produced by many publishers, so the most useful mode of reference is to chapters, sections, and the like, most of which are brief. See Thomas Hobbes, Leviathan, chs. 13-18 (1651); John Locke, Two Treatises of Government, Book $2 \S \S 4-6,17-21,27,28,30$, and 211 (1690); David Hume, A Treatise of Human Nature, Book 3, Part 2, § 2 (1740); William Blackstone, Commentaries on the Laws of England (1765-1769), 2:3-8.

7. See, e.g., Thomas C. Hayes, "Confrontation in the Gulf: The Oilfield Lying Below the Iraq-Kuwait Dispute," New York Times, Sept. 3, 1990, § 1, at 7, discussing the Rumaila 
(3) The majority in Pierson chose the rule of capture, as described above. The dissenting judge favored an approach whereby the first to pursue should prevail, provided there was a reasonable prospect of capture. ${ }^{8}$ Notice that both positions are subsumed under the more general principle of first-intime commonly offered up as a way to resolve disputes over property. The general principle, we can see, is too general, because it neglects the issue of first what in time. So which should it be-capture, or chase? The majority opted for the first alternative on both formalistic and instrumental grounds. The formalist urge led it to follow the view of classic jurisprudential commentators (much mocked by the dissent), ${ }^{9}$ and instrumental reasons supported that choice. The majority wanted a clear and certain rule, and here capture served best: it's easier to determine who first caught a fox than to determine, as the dissenting judge would have it, who first pursued it with a reasonable prospect of capture. The dissent, in contrast, took a strictly instrumental approach; the judge reasoned that the end in question was to promote the killing of foxes, which were regarded back then as noxious

pool, a huge oil formation beneath Iraq and Kuwait. Most of the oil underlies Iraq, but in the 1980 s the bulk of it was withdrawn by Kuwait. "Kuwait's wells could eventually, in theory, bring up oil from the entire Rumaila pool." Iraq saw this as theft.

8. Both Fernandez and Donahue suggest that Pierson might more properly have been decided according to a tort theory of interference with capture rather than the property theory developed in the case; the result then, they think, might well have been different. See Angela Fernandez, "The Lost Record of Pierson v. Post," Law and History Review 27 (Spring 2009): 168, and Charles Donahue, Jr., "Papyrology and 3 Caines 175," ibid., 181. As Donahue notes in his discussion, the majority opinion in Pierson in fact mentioned (but distinguished) the most directly relevant case on interference, namely Keeble v. Hickeringill, 11 East 574, 103 Eng. Rep. 1127 (K. B. 1707). The case is referred to in Pierson only by a citation to 11 Mod. 74-130, and 3 Salk. 9, without the names of the parties. Both of the early accounts cited in Pierson are considered unreliable.

My own opinion is that if interference had been the theory applied, still the Pierson case should have been resolved exactly as it was. (Whether it actually would have been resolved in the same manner is, of course, hardly clear.) From an instrumental point of view-where the end in mind is to have rules that promote constructive competition in the production of goods-both Pierson and Keeble reached the right result. For an explanation and defense of that view, see James E. Krier, "Capture and Counteraction: Self-Help by Environmental Zealots," University of Richmond Law Review 30 (1997): 1039.

9. Rather than making fun of the majority's method, the dissenting judge might have studied the classics for himself. John Locke, for example, argued from his labor theory of property that on facts like those in Pierson, a wild animal should rightly go to the person who invested labor in pursuit, notwithstanding capture had not yet been achieved. See Locke, Two Treatises of Government, Book $2 \S 30$ ("the hare that anyone is hunting, is thought his who pursues her during the chase. For being a beast that is still looked upon as common, ... whoever has employed so much labor about any of that kind, as to find and pursue her, has thereby removed her from the state of nature, wherein she was common, and hath begun a property"). This was exactly the result advocated in the dissenting opinion. 
beasts and a menace to chickens. Judicial formalism was the standard practice when Pierson was decided, whereas transparent instrumentalism was rare. Today that pattern is reversed, but both approaches still figure regularly in legal arguments and decisions, so there is value in exposing students to the comparative advantages of each.

(4) The rule of capture is just that-a firm fixed rule. The approach of the dissent is what we would today call a standard, as opposed to a rule. (An example of a rule is a stop sign posted on a roadway; an example of a standard is a sign that says "drive carefully when roads are wet.") The majority's rule has the virtue of certainty, but the vice of inflexibility; the dissent's standard is just the opposite. How do we trade off, then, between rules and standards, certainty and flexibility? The issue comes up in ever so many contexts (and is the subject of a large literature of which students should at least be aware).

(5) Relatedly, the dissenting judge believed his standard would better serve the instrumental end (getting rid of foxes) than would the majority's firm rule. There is ample reason to suppose that he was wrong: countless empirical studies show that the rule of capture is a ruthlessly effective way to deplete resources. The lesson in any event is that while it's sensible for judges to reason from instrumental ends to the means by which to achieve them, it's important that judges know what they're talking about when it comes to the impact of various alternative legal rules on human behavior. Once students are sensitized to the point, they find evidence in many cases that judges are fully capable of extraordinarily dubious conclusions in this respect.

(6) The dissent suggested that the best way to deal with the dispute in Pierson would be to let fox hunters decide it in light of their own customs. The role of custom in law-making comes up often in property and other courses. It tends to appeal to the fresh student mind, until the professor suggests to his students that perhaps, then, the professor's customs should resolve all disputes that arise about when the class will meet for make-ups, whether students must participate, how they are to be graded, and so on. Why should the particular custom of any individual or group play a role in deciding a contest between the party who relies on custom (fox hunters, say), on the one hand, and everybody else on the other (say the population at large, or the population of conservationists, or the population of people who are members of the ASPCA)? The short answer is, it shouldn't generally, although in some contexts (mainly where competitive markets are at work) there is no problem.

I imagine that legal historians could provide me with information that bears on some of these themes. So far, however, at least as to Pierson $v$. Post, I find many facts in the historical accounts, but little information. So, 
too, for the newly discovered record; for me it yields virtually nothing. ${ }^{10}$ Professors Fernandez and Donahue, on the other hand, find in it much that suits their aims, and rightly so. Facts are facts (we hope!). Information is in the eye of the beholder.

10. One bit dug up by Fernandez did catch my attention. The costs of the famous fox litigation, adjusted to the present, came to only some $\$ 2,260$. Now that's interesting, but also depressing. Nowadays, justice comes more dear. 